\author{
Joanna Wartak*, Katarzyna Chruszcz-Lipska*, Ewa Knapik*, \\ Stanisław Rychlicki*
}

\title{
SOIL CONTAMINATION BY PETROLEUM SUBSTANCES IN THE VICINITY OF OIL PRODUCTION WELLS**
}

\section{INTRODUCTION}

The Act of 27 April 2001 - Environmental protection law (Journal of Laws 2001 No. 62, item 627) defines soil as the upper part of the lithosphere, which consists of a mineral part, an organic part, soil water, soil air and organisms, covering the top part of the ground and subsoil [4].The soil-forming process is very slow, therefore soil resources are basically regarded as non-renewable. Among the basic functions of soil in on-land ecosystems mainly are filtering and buffering activity, protection against excessive flow of various elements and compounds as well as substances of anthropogenic origin to other elements of biosphere, mainly waters and plants. Soil is a source of food, biomass, raw minerals and is a platform for landscape and human activity [1,2].

Maintaining soil and ground at a required quality level allows for maintaining functions played by the lithosphere without changes. The quality of soil and land is assessed due to the presence of different types of pollution (metals, inorganic contaminants, hydrocarbons, chlorinated hydrocarbons, pesticides etc.). On the other hand, the results of impacts exerted by contaminations depend on various factors, e.g. climate, physicochemical and biological properties of soil, the history of contamination, the way in which the area is used, accompanying contaminations, pathways through which contamination are transported, etc.

In Poland soil and ground assessments and observation of changes in the contamination level are performed pursuant within the Polish environmental monitoring program [4]. The monitoring of arable grounds chemistry in Poland has been conducted since 1995 in 5-year cycles. In Poland arable soils are chemically analyzed at the Institute of Soil Science and

* AGH University of Science and Technology, Faculty of Drilling, Oil and Gas, Krakow, Poland

** The research leading to these results has received funding from the Polish-Norwegian Research Programme operated by the National Centre for Research and Development under the Norwegian Financial Mechanism 2009-2014 in the frame of Project Contract No Pol-Nor/235294/99/2014. The research was partially financed by AGH University of Science and Technology under grant No. 15.11.190.650/2016 
Plant Cultivation (ISSPC), although Provincial Inspectors of Environmental Protection can service voivodeships or local regions as well [3].

Petroleum products belong to the most frequent contaminations appearing in the soil-water environment [2]. Some compounds (including BTX and PAHs) are highly toxic for the living organisms. Besides they are characterized by relative resistivity to biochemical decomposition, and capability to adsorb and bioaccumulate [9]. The contamination of soil with petroleum products directly affects the quality of water and air, biological diversity and climate. It also has a negative impact on human health and is dangerous for food. Thus, the qualitative evaluation of soil in view of these contaminations is a very important issue. It is of particular importance for agricultural areas and near watercourses being in contact with water intended for human consumption.

BTX and PAHs pollutions are common due to the widespread exploitation, transportation, storage, and processing of crude oil and its products. Many researchers had described the PAHs contaminated soils from different locations. This type of environmental pollution related to the oil extraction was reported inter alia for Niger Delta [6], the province of Alberta, Canada [10], the Yellow River Delta region [11] and the Gulf of Mexico [12]. In Poland according to the report of the Chief Inspectorate of Environmental Protection, in terms of the content of polycyclic aromatic hydrocarbons (PAHs) $76 \%$ of arable soils can be considered as not contaminated, whereas $24 \%$ of soils is contaminated at low and medium levels [13]. Numberous reports show that only small areas where hydrocarbons are directly exploitated or refined exhibit higher PAHs content. Macuda et al. [14] measured PAHs content in water and soil samples taken from the area of selected Polish oil refinery. The content of studied PAHs in soil samples ranges from 411 to $101,439 \mu \mathrm{g} / \mathrm{kg}$ and in groundwater from 1.05 to $568.09 \mu \mathrm{g} / \mathrm{dm}^{3}$ what indicates the necessary of area remediation. Malina et al reported the direct hazard to the Upper Jurassic and Quaternary aquifers from 27 petrol stations in the Częstochowa region [15]. Zacharyasz et al. [16] reported for Międzychód area a heavy contamination by petroleum substances due to pipeline failure in 1996. Until today, the contamination has spread beyond due to favorable hydrological conditions. The potential impact of exploitation of oil fields in the Polish economic zone of the Baltic Sea was assessed by Małaczyński et al. [17]. Rybicki et al. discussed environmental problems relating to abandoned hydrocarbon oil fields [18]. Solid wastes generated during drilling operations are also a potential source of PAHs. An increased mineral oil index was reported for Grabownica oil field where drilling wastes were stored in an open pit without any treatment [19].

The main goal of this work was the study of soil quality in the vicinity of oil production wells in the selected region of active oil exploitation. Regular measurements are required to mitigate the negative impact of mining activities on the environment. As an indicator of soil contamination by petroleum products the concentrations of aromatic hydrocarbons (selected BTX and PAHs) in soil samples were investigated.

\section{METHODOLOGY}

\section{Sample collection}

Nineteen soil samples analyzed in this work were collected near production wells on the area of two oil fields in the south of Poland. Six sampling places were localized at $1 \mathrm{~m}$ 
distance from the wells, whereas the remaining thirteen samples at a distance of 1 to $7 \mathrm{~m}$. The samples were taken at a depth of 0.1 to $0.3 \mathrm{~m}$.

\section{Chromatography measurements}

Before starting the treatment, the soil sample was refrigerated for 48 hours at $-35^{\circ} \mathrm{C}$, to the destruction of more compact structures and to allow for efficient penetration of solvent. Soil sample was subjected to continuous extraction in solid-liquid Soxhlet extractors. Extraction thimbles were made from 289 type filter paper. The extraction was carried out using $200 \mathrm{~cm}^{3}$ of dichloromethane as a solvent. The mass of the extracted sample was equal to $50 \mathrm{~g}$, and the extraction time was 7 days. Before extraction the solution of recovery standard was added to the sample. As the standard $250 \mu \mathrm{lof} 20 \mu \mathrm{g} / \mathrm{cm}^{3}$ perylene solution was used. After 7 days chromatographic and UV-vis spectrophotometric measurements of the solvent contained in the extraction chamber, just before the overflow down, were done. There was no presence of other substances besides solvent. This shows that all substances that could be extracted using this procedure were extracted. The extract was then quantitatively transferred to an A class volumetric flask with a volume of $250 \mathrm{~cm}^{3}$.

$100 \mathrm{~cm}^{3}$ of extract was taken by Mohr pipette and then transferred to evaporating flask and the solvent was evaporated in the flow of dry inert gas while maintaining the temperature of the solution did not exceed $15^{\circ} \mathrm{C}$. The residue was weighed on an analytical balance, transferred to a $10 \mathrm{~cm}^{3}$ A type volumetric flask, and then $1 \mathrm{~cm}^{3}$ of solution was taken to chromatographic vial. Then $40 \mu \mathrm{l}$ of solution of internal standard was added. The sample thus prepared was subjected to gas chromatographic analysis. The analysis was performed using HP 5890 gas chromatograph under the conditions shown below:

- splitless type inlet system,

- temperature of inlet system: $300^{\circ} \mathrm{C}$,

- septum purge flow rate: $3 \mathrm{~cm}^{3} / \mathrm{min}$,

- detector: FID,

- temperature of detector: $320^{\circ} \mathrm{C}$,

- hydrogen flow rate through detector: $30 \mathrm{~cm}^{3} / \mathrm{min}$,

- air flow rate through detector: $300 \mathrm{~cm}^{3} / \mathrm{min}$,

- carrier gas: nitrogen,

- carrier gas flow rate: $5 \mathrm{~cm}^{3} / \mathrm{min}$,

- Inlet Liner $4 \mathrm{~mm}$ splitless one trap with quartz wool,

- chromatography column RTX-5 with a length of $60 \mathrm{~m}, 0.53 \mathrm{~mm}$ diameter and $1 \mu \mathrm{m}$ thickness of the stationary phase,

- temperature program:

- initial temperature $35^{\circ} \mathrm{C}$, holding time $3 \mathrm{~min}$,

- first temperature ramp: rate $10^{\circ} \mathrm{C} / \mathrm{min}$, final temperature $200^{\circ} \mathrm{C}$,

- second temperature ramp: rate $4^{\circ} \mathrm{C} / \mathrm{min}$, final temperature $300^{\circ} \mathrm{C}$,

- final temperature $300^{\circ} \mathrm{C}$, holding time $40 \mathrm{~min}$.

Application of an initial column temperature below the boiling point of the solvent led the condensation of the sample at the beginning of the column to produce a more compact area in which the sample was found. This allows for the improvement of the separation characteristics of the sample. Furthermore, measurements of soil moisture using a moisture balance were performed. The results of soil analyzes were calculated on the dry weight. 


\section{RESULTS AND DISCUSSION}

The soil and ground quality standards were determined according to the Regulation of the Ministry of Environment of 1 September 2016 regarding the assessment of contamination of the surface of the earth (Journal of Laws 2016 No. 0, item 1395) [5]. According to that Regulation there are four groups of land identified on the basis of the manner of their use in a given area (determined according to the records of land and buildings), where:

- group I - includes residential areas, other built-up areas, undeveloped urbanized area or those under development, built-up agricultural lands, recreational areas (areas of recreation centers, playgrounds for children, beaches, parks, squares, green areas, sports grounds, areas performing entertainment functions, zoological and botanical gardens), excluding areas listed in group III,

- group II - includes arable land, orchards, permanent meadows, permanent pastures, land under ponds, areas under ditches, and areas of family allotment,

- group III - includes forests, land grown with trees and bushes, land grown with trees and bushes on agricultural land, wasteland, ecological areas, recreational areas (historic areas, green, undeveloped areas not classified as forests and lands grown with trees and bushes) excluding areas listed in group I,

- group IV - applies to industrial areas, mining land, communication areas (roads, railway areas, other areas of communication, land designated for construction of public roads and railways).

The experimental results obtained for soil samples collected near production wells originated from two oil deposits located in the south of Poland are presented in Table 1. The values obtained by measuring the concentrations of selected petroleum substances in the soil samples were compared with the standards set out in [5].

As mentioned above, the analyzed soil samples can be divided into two groups: the first group with six samples 1-6 which were collected at $1 \mathrm{~m}$ distance from the wells, and the second group with samples 7-19 which were collected at a distance of 1 to $7 \mathrm{~m}$ from the producing well. Without a doubt, samples 1-6 are localized on the mining land. Thus, soil from that area should be classified to group IV of ground (applies to industrial areas, mining land, communication areas, etc.) according to [5].

The second group of samples was collected from areas used as agricultural parcels. Therefore, in the opinion of the authors, the area of collection of those soil samples can be classified into the group II of ground (includes arable land, orchards, permanent meadows, permanent pastures, etc.) according to [5].

In soils from group IV, the permissible content of aromatic hydrocarbons in the environment for benzene, toluene and xylene is less than $100 \mathrm{mg} / \mathrm{kg}$. Analyzing the concentration of a particular aromatic hydrocarbons of investigated soil samples 1-6 (Tab. 1), it can be seen that the obtained experimental values are below the limits. In the case of the lands from group II the allowed content of benzene toluene and xylene in the environment does not exceed $0.1 \mathrm{mg} / \mathrm{kg}$.

The experimental results show that the environmental quality standards were exceeded for BTX content in samples 7-13. The highest concentration of BTX is observed in the samples $8(16.6 \mathrm{mg} / \mathrm{kg})$ and the lowest for the sample $19(1.4 \mathrm{mg} / \mathrm{kg})$. 


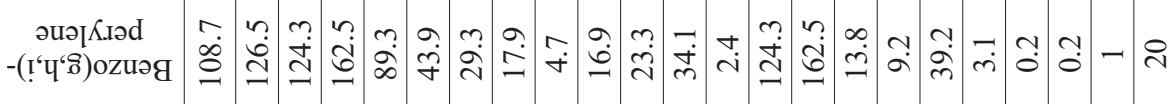

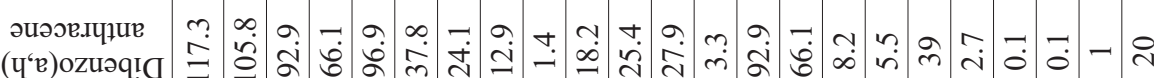

-

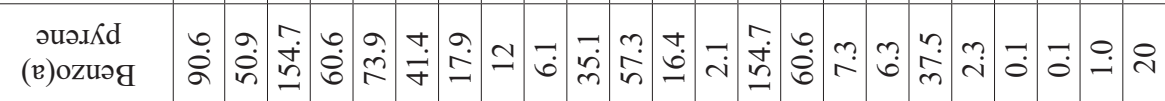

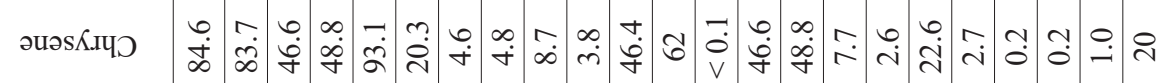

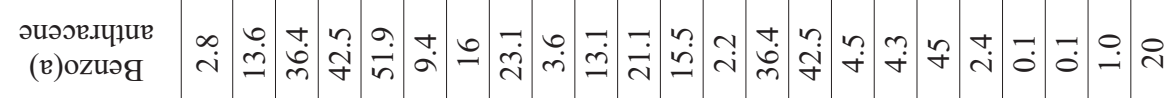

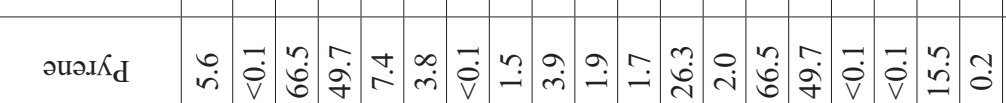

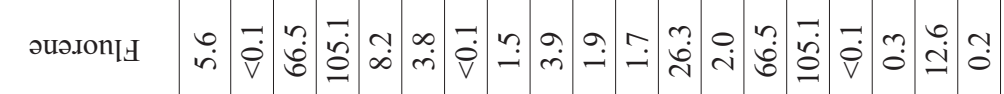

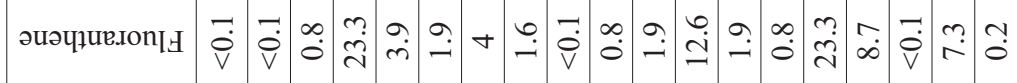

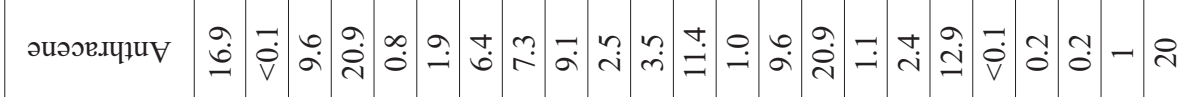

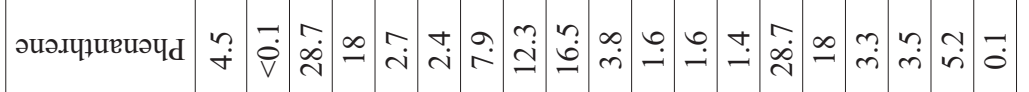

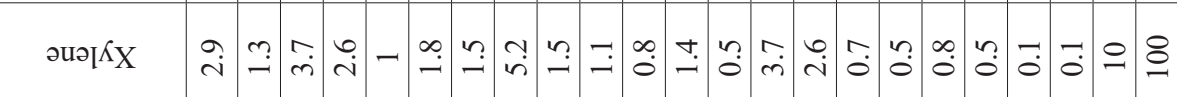

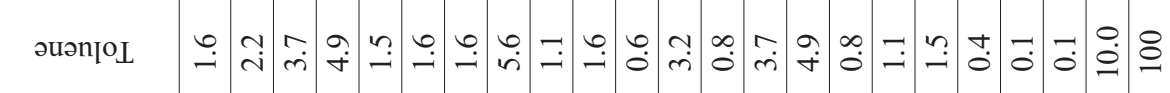

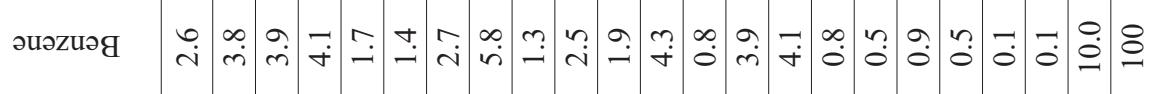

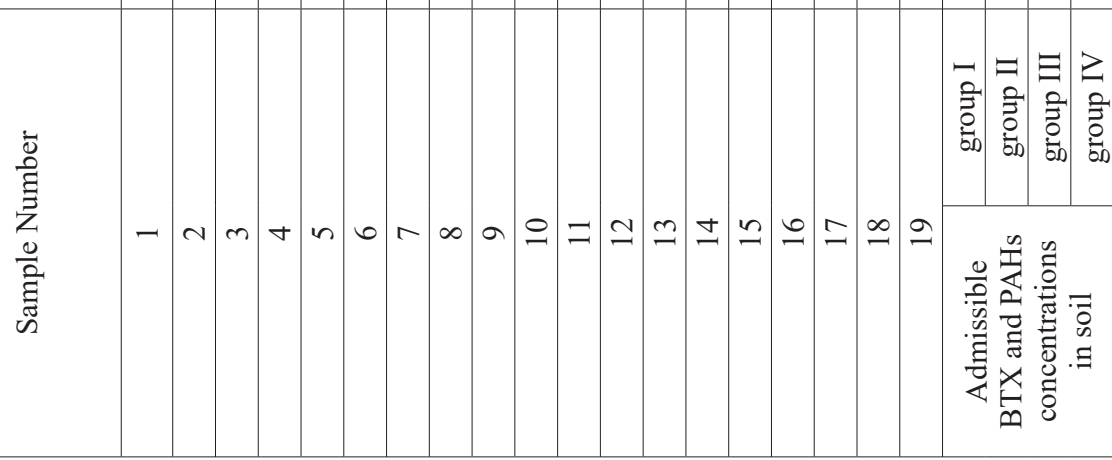


The maximal accessible content of each of the compounds belonging to the group of PAHs, for the lands from group IV should not exceed $20 \mathrm{mg} / \mathrm{kg}$. Among the group of compounds belonging to PAHs the concentrations of the phenanthrene, anthracene, fluoranthene, fluorine, pyrene, benzo(a)anthracene, chrysene, benzo(a)pyrene, dibenzo(a,h)-anthracene, benzo(g,h,i)-perylene were measured. Analyzing the result of the obtained measurements it can be observed that the concentration of PAHs in the soil samples 1-6 is very high, and exceeds limits for that type of ground. For lands from group II values of measured concentrations of hydrocarbons in the case of all samples (7-19) exceed the limit values, therefore, they should be considered as contaminated. Significant outranking of the admissible concentration in the samples located at some distance from the operational wells indicates that the concentrations of hydrocarbons in the soil in an area of agricultural parcels adjacent to the area of operation may also not meet the environmental standards.

The contamination of soil environment with crude oil and its products is an important environmental issue. One of the major sources of such contaminations are oil handling systems and facilities. Most oil products are toxic for living organisms - flora, fauna and also human health. These compounds also negatively influence the physicochemical properties of the soil-water environment [8]. Under the influence of oil soil gets clumped and the spaces through which air and water are transported close. The presence of petroleum products lowers the sorption capacity of soil and assimilability of compounds of potassium, magnesium and phosphorus; additionally, it causes excessive growth of carbon compounds [1]. The resulting disturbed biological equilibrium leads to a high deficiency of oxygen in soil and shortage of assimilable forms of nitrogen and phosphorus compounds. As a result of these negative changes, the seeds are destroyed and the crops are lower [3]. Organic contaminations, e.g. PAHs and BTX can be taken by plants from soil and transported to surface - and groundwaters to finally reach animal and human organisms. Some aromatic hydrocarbons present in the soil are very dangerous for human beings because of their high toxicity and carcinogenic effect [6]. Low mobility and long life of PAHs cause that they are preserved in the ground structure which is exposed to these contaminations for a long time. As a consequence the substances are very hard to remove. The polycyclic aromatic hydrocarbons commonly appear in the environment. However, when certain threshold values are exceeded they may be dangerous for the environment and also for human health, therefore finding out the concentrations of these substances in soil is of primary significance [7, 9].

Soil quality in Poland is also evaluated on the basis of guidelines of the Institute of Soil Science and Plant Cultivation (ISSPC). The soil quality evaluation method worked out by ISSPC is based on graded scales of soil contamination depending on the content of heavy metals, sulphur and polycyclic aromatic hydrocarbons. Soil properties are taken into account in this system (e.g., organic matter content granulometric composition), which may have an influence on the bioaccessability and ability to penetrate deeper layers of soil and groundwater. The assumed boundary values define the admissible contamination content. The ISSPC guidelines were used for arable lands, though the assumed criteria were frequently referred to roughly estimate the contamination level in areas which have been used in a different manner [3].

The classification of PAHs contaminated soils accounts for the total of 13 compounds from this group, standardized to standard soil (2\% organic matter) and the ground is divided into 6 contamination classes [20]. 
Table 2

Boundary PAHs values (referring to soil $\leq 2.0 \%$ organic matter) in $0-20 \mathrm{~cm}$ soil layer

\begin{tabular}{|c|c|l|}
\hline $\begin{array}{c}\text { Sum of } \mathrm{PAHs}^{\mathrm{A}} \\
\text { content in } \mu \mathrm{g} / \mathrm{kg} \text { of soil }\end{array}$ & $\begin{array}{c}\text { Contamination } \\
\text { level }\end{array}$ & \multicolumn{1}{|c|}{ Evaluation of soil contamination level } \\
\hline$<200$ & 0 & not contaminated (natural content) \\
\hline $200-600$ & 1 & not contaminated (higher content) \\
\hline $600-1,000$ & 2 & low contamination \\
\hline $1,000-5,000$ & 3 & contaminated \\
\hline $5,000-10,000$ & 4 & highly contaminated \\
\hline$>10,000$ & 5 & very strongly contaminated \\
\hline
\end{tabular}

A - Sum of 13 PAHs compounds: fluorene, phenanthrene, anthracene, fluorantene, pyrene, benzo(a) anthracene, chrysene, benzo(b)fluorantene, benzo(k)fluorantene, benzo(a)pyrene, dibenzo(a,h)anthracene, indeno(1,2,3-cd)pyrene, bezo(g,h,i)perylene (after "US EPA List")

The level of arable soil contamination with heavy metals and polycyclic aromatic hydrocarbons determines the way in which the land will be used. Soils at contamination level 0-1 can be used for the cultivation of all plants without the risk of contaminating crops with PAHs. The cultivation of plants in considerably contaminated soils (2 to 4) creates hazards that they will be contaminated with PAHs. In soils contaminated at a level of 2 the cultivation should be limited to the production of food which is low in contaminants, i.e. for children and infants. Serious contamination of the crops, especially root vegetable and leaf vegetable may be observed in soils at a contamination level 4. Contaminated soils (level 3), especially highly contaminated (level 4) should rather be not used for grassland (grazing and hay production). As far as soils of category 5 are concerned, there exists a serious danger that all vegetation in such strongly contaminated conditions may be contaminated with PAHs. Such soils should be preferably excluded from agricultural use [2].

When evaluating soil quality according to the guidelines of the Institute of Soil Science and Plant Cultivation (ISSPC), such soils should be considered as extremely contaminated. Although the measured PAHs concentrations refer to only 9 of 13 compounds in the ISSPC guidelines, they considerably exceeded $10 \mathrm{mg} / \mathrm{kg}$ in each of the samples.

\section{CONCLUSIONS}

It is obvious that the region of oil exploitation is a potential source of contamination by hydrocarbons. In particular the area in the vicinity of oil production wells is exposed to pollution. The aromatic structures such as BTX and PAHs present in the crude oil belong to the most hazardous hydrocarbons in the environment. Therefore, the content of these substances in environmental samples is indicative of the level of contamination of the environment. Measured concentrations of those hydrocarbons in the analyzed area frequently exceeded the admissible values. As long as this is the mining land and is used industrially environmental threat is not large. However, the adjacent areas are often used for agricultural purposes and the plants grow in the close vicinity of the producing wells. It makes the issue serious and it 
may really create hazard for the environment and human health. The measured concentrations of PAHs and BTX in all soil samples, even in $7 \mathrm{~m}$ distance from the operating well does not meet standards for land of II class (includes arable land, orchards, permanent meadows, permanent pastures, land under ponds, areas under ditches, and areas of family allotment). The results of the research suggest determining a bigger area around the producing wells where the cultivation of crops should be banned.

\section{REFERENCES}

[1] Gierak A.: Zagrożenie środowiska produktami ropopochodnymi. Ochrona Środowiska, nr 2(57), 1995, pp. 31-34.

[2] Maliszewska-Korybach B., Smreczak B., Klimkowicz-Pawlas A., Terelak H.: Monitoring of the total content of polycyclic aromatic hydrocarbons (PAHs) in arable soils in Poland. Chemosphere, vol. 73, 2008, pp. 1284-1291.

[3] Maliszewska-Kordybach B., Smreczak B., Klimkowicz-Pawlas A.: Zagrożenie zanieczyszczeniami chemicznymi gleb na obszarach rolniczych $w$ Polsce $w$ świetle badań IUNG-PIB w Puławach. Studia i Raporty IUNG-PIB 35, vol. 9, 2014, pp. 97-118.

[4] Ustawa z dnia 27 kwietnia 2001 r. Prawo ochrony środowiska. Dz.U. 2001, nr 62, poz. 627 z późn. zm.

[5] Rozporządzenie Ministra Środowiska z dnia 1 września 2016 r. w sprawie sposobu prowadzenia oceny zanieczyszczenia powierzchni ziemi. Dz.U. 2016 nr 0, poz. 1359.

[6] Sojinu S., Wang J-Z., Sonibare O., Zeng E.: Polycyclic aromatic hydrocarbons in sediments and soils from oil exploration areas of the Niger Delta, Nigeria. Journal of Hazardous Materials, vol. 174, no. 1, 2010, pp. 641-647.

[7] Strategia UE KOM (231) Strategia tematyczna w dziedzinie ochrony gleby - wersja ostateczna, 2006: Komunikat Komisji do Rady, Parlamentu Europejskiego, Europejskiego Komitetu Ekonomiczno-Społecznego oraz Komitetu Regionów, 2006.

[8] Tsibart A.S., Gennadiev A.N.: Polycyclic aromatic hydrocarbons in soils: sources, behavior, and indication significance. Eurasian Soil Science, vol. 46, no. 7, 2013, pp. 728-741.

[9] Włóka D., Smol M.: Ocena stopnia zanieczyszczenia wielopierścieniowymi węglowodorami aromatycznymi (PAH) gleb nawożonych osadami ściekowymi, Inżynieria i Ochrona Środowiska, t. 17, nr 4, 2014, pp. 713-726.

[10] Sherval M.: Canada's oil sands: The mark of a new 'oil age'or a potential threat to Arctic security?. The Extractive Industries and Society, vol. 2, no. 2, 2015, pp. 225-236.

[11] Gao Y., Wang J., Guo S., Hu Y., Li T., Mao R., Zeng D.: Effects of salinization and crude oil contamination on soil bacterial community structure in the Yellow River Delta region, China. Applied Soil Ecology, vol. 86, 2015, pp. 165-173.

[12] Harding V., Camp J., Morgan L.J., Gryko J.: Oil residue contamination of continental shelf sediments of the Gulf of Mexico. Marine Pollution Bulletin, 2016 [in print].

[13] State of the environment in Poland 2014, Chief Inspectorate for Environmental Protection.http://www.gios.gov.pl/images/dokumenty/pms/raporty/GIOS_raport_2014.pdf [Access 20.07.2016]. 
[14] Macuda J., Solecki T.: Zanieczyszczenie środowiska gruntowo-wodnego wielopierścieniowymi węglowodorami aromatycznymi w rejonie rafinerii. Inżynieria Środowiska, t. 10, nr 1, 2005, pp. 89-97.

[15] Malina G., Deska I., Derda A., Derda M.: Risk assesment from petrol stations to groundwater in Częstochowa region - Poland. Proceedings of the Seventh International FZK/TNO Conference on Contaminated Soil, 18-22 September 2000, Leipzig, Germany.

[16] Zacharyasz P., Siepak J., Rosada J.: Petroleum-contaminated soil and water analysis and biodegradation. Polish Journal of Environmental Study, vol. 21, no. 5, 2012, pp. 1467-1480.

[17] Małaczyński K., Czarnecki J.: Zagrożenia wynikajace z eksploatacji złóż ropy naftowej w szelfie Morza Bałtyckiego. http://www.gios.gov.pl/images/dokumenty/powazne_ awarie/zagrozenia_20110325.pdf [Access 20.07.2016].

[18] Rybicki C., Solecki T., Winid B.: Threats to the environment in the areas of abondoned extraction of hydrocarbon deposits. AGH Drilling, Oil, Gas, vol. 32, no. 1, 2015, pp. 103-120.

[19] Macuda J.: Badania gleb i gruntów w rejonie miejsc wieloletniego składowania odpadów wiertniczych i poeksploatacyjnych. AGH Drilling, Oil, Gas, vol. 29, no. 1, 2012, pp. 265-270.

[20] Kabata-Pendias A., Piotrowska M.: Podstawy oceny chemicznego zanieczyszczenia gleb. Metale ciężkie, siarka i WWA. Biblioteka Monitoringu Środowiska, PIOŚ, IUNG, Warszawa 1995. 